\title{
Measuring the Sun Depression Angle of Dawn with a DSLR Camera
}

(Mengukur Sudut Junaman Matahari bagi Fajar menggunakan Kamera DSLR)

\author{
KASSIM BAHALI*, ABDUl LATIF SAMIAN, NAZRI MUSLIM \& NURUl SHAZANA ABDUl Hamid
}

\begin{abstract}
The first visibility of the dawn occurs at a definite angle of the sun depression, $D_{o}$ which is used to calculate the fajr (dawn) prayer time. Dawn observations were carried out using Digital Single-lens Reflex (DSLR) camera in the period from February to December 2017 at several locations in both Malaysia and Indonesia (Lat. between $2.0^{\circ}-7.0^{\circ} \mathrm{N}$, Long. 95. $0^{\circ}-106.0^{\circ} \mathrm{E}$ ). Within the observational period, 64 days of the dawn luminance at horizon were recorded with backgrounds of both sea and land. The purpose of these observations was to determine the sun depression angle $D_{o}$ at the first moment when the dawn is seen using a DSLR camera. The results indicated that $D_{0}$ can be determined using a DSLR camera. The value of $D_{o}$ is between $-14.5^{\circ}$ and $-18.5^{\circ}$ with a mean value of $-16.67^{\circ}$ and standard deviation of 0.9992. This suggests that the new sun depression angle $D_{o}$ for dawn prayer is $-17.0^{\circ}$.
\end{abstract}

Keywords: Dawn; digital camera; sun depression angle

\section{ABSTRAK}

Fajar mula-mula kelihatan berlaku pada suatu sudut junaman matahari $D_{o}$ yang tertentu yang digunakan untuk menghitung waktu solat subuh. Pencerapan fajar telah dilakukan menggunakan kamera digital kanta pemantul tunggal (DSLR) dalam tempoh dari Februari hingga Disember 2017 di beberapa lokasi di Malaysia dan Indonesia (Lat. di antara $2.0^{\circ}-7.0^{\circ} \mathrm{U}$, Long. $95.0^{\circ}-106.0^{\circ} \mathrm{T}$ ). Dalam tempoh tersebut, 64 data cerapan kecerahan fajar di ufuk laut dan daratan telah direkodkan. Tujuan pencerapan ini adalah untuk menentukan sudut junaman matahari $D_{o}$ ketika fajar mula-mula kelihatan dengan kamera DSLR. Keputusan kajian menunjukkan D boleh ditentukan dengan kamera DSLR dan nilai Do di antara $-14.5^{\circ}$ hingga $-18.5^{\circ}$ dengan min $-16.67^{\circ}$ dan sisihan piawai 0.9992. Dengan hal demikian, dicadangkan nilai sudut junaman baharu $D_{0}$ bagi solat subuh ialah $-17.0^{\circ}$.

Kata kunci: Fajar; kamera digital; sudut junaman matahari

\section{INTRODUCTION}

According to Islamic religion, fajr (dawn) prayer time is determined with the rising of dawn. In the early Islamic era, prayers time were determined based on astronomical phenomena observations such as sun transit and sunset. However, nowadays the time is based on calculation. In the Malay world, especially in Malaysia and Indonesia, the time is determined by astronomical calculations using a sun depression angle below the horizon of either $-19^{\circ}$ (Kelantan state) and $-20^{\circ}$ (other states and Indonesia) (Baharrudin 2002). Unfortunately, these values have been adopted without scientific evidence.

The optical phenomenon of twilight occurs near the time of sunrise and sunset. The sky still appears bright after the sun has set or before it has risen in the morning. If the earth had no atmosphere, the sky would be dark immediately after sunset (or before sunrise). The appearance of the sky is dependent on the sun's altitude. At certain altitudes, although the sun is below the horizon, the sky appears bright. This is caused by the sun's rays being scattered by the earth's atmosphere. Once light enters the earth's atmosphere, it is reflected, refracted and scattered. When this happens, the atmosphere's molecules scatters sunlight in all directions, giving the sky a faint glow. As the sun moves further below the horizon, the sky becomes darker. There is no light scattering when the sun's altitude is $20^{\circ} \pm 2^{\circ}$ below the horizon (Ilyas 1984).

The sky and twilight brightness were studied by Duriscoe (2016), Hanel et al. (2018) and Kishida (1989), by photoelectric measurements. Studies on dawn have been carried out using two methods: Naked eye observations and photoelectric measurements. Naked eye observations were conducted by Hassan (2014) in four locations in Egypt and photometer observations were used by Dhani (2016), Hassan (2014, 2013), Issa (2008) and Issa and Hassan (2008).

\section{MATERIALS AND METHODS}

\section{INSTRUMENTATION AND CALIBRATION}

The authors used DSLR imaging methods to detect and measure the first light of dawn. Nowadays DSLR cameras offer the advantage of being easy to use with a wide range of standard camera lenses. They are also useable with telescopes and produce color images without a 
separate filter. Modern DSLRs have excellent technical specifications. Readout noise is typically under 10 electrons root mean square (r.m.s) and dark current is low enough to allow exposures of 4 min or longer, depending on ambient temperature (Berry \& Burnell 2005). DSLRs are used in imaging devices for precision photometry to measure the brightness of stars. They are sufficient to records stars light in three colors simultaneously (Zhang et al. 2016). With these significant advantages, we used DSLR cameras for the detection and measurement of the luminance of dawn.

To use a DSLR camera for measurement of luminance, it should be calibrated with a conversion factor that links luminance to the value of a pixel in an image. The image taken by the DSLR camera records into a two-dimensional array of pixels. Each pixel has a value which represents the light intensity at that point. The amount of the luminance of the image is proportional to the number of electrons that are released by the photons of light falls on the sensor, where the luminance (in lux-seconds) is proportional to illuminance (in lux) times the exposure time (in seconds). Invoking the parameter of the camera, the formula can be derived as follows (Hiscocks 2014):

$$
N_{e}=K_{c}\left(\frac{t S}{f_{s}^{2}}\right) L_{S}
$$

where $\mathrm{N}_{\mathrm{d}}$ is the digital number (pixel value) of the pixel in the image; $\mathrm{K}_{\mathrm{c}}$ is the calibration constant for the camera; $t$ is the exposure time; $f_{s}$ is the aperture number ( $\mathrm{f} / \mathrm{stop}$ ); $\mathrm{S}$ is the ISO sensitivity of the film and $\mathrm{L}_{\mathrm{s}}$ is the luminance of the scene.

The digital number (pixel value) $\mathrm{N}_{\mathrm{d}}$ of a pixel is determined from an analysis of the image using Astronomical Image Processing for Windows (AIP4Win) an image processing software. Pixel value $\mathrm{N}_{\mathrm{d}}$ is directly proportional to scene luminance $\mathrm{L}_{\mathrm{s}}$. It is also dependent on settings such as exposure time $t$, aperture number $f_{s}$ and ISO sensitivity of the sensor or film. For example, if the exposure times are doubled, the pixel number should also double.

The calibration constant $\mathrm{K}_{\mathrm{c}}$ is calculated by using the formula (1) with a known luminance value, exposure time, aperture number and ISO sensitivity of the sensor of the DSLR camera.

Typical luminance values are (Hiscocks 2014):

Light source - Luminance, candela per square meter; Sun - $1.6 \times 10^{9}$, Arc lamp - $1.5 \times 10^{8}$, Cloud (sunny day) - 35000; 60 watt soft-white bulb - 10000; Surface of moon - 1000; Neon lamp - 8; Candle - 7.5; White paper lit by candle (at $1 \mathrm{ft}$ ) - 0.29; Night dark sky - 0.001; and Horizon at sun altitude $-9^{0}-0.01-0.1$.

Pixel values are represented inside the camera in binary. The range for the pixel value $\mathrm{N}_{\mathrm{d}}$ is from 0 to $\mathrm{N}_{\max }$, where:

$$
N_{\max }=2^{B}-1
$$

where $\mathrm{B}$ is the number of bits in binary. For example, in a 16-bit camera, $\mathrm{N}_{\max }=2^{16}-1$.

For the camera with 16 bit raw image, the range of values is from 0 to 65,535 . In order not to lose information in the image, exposure must not exceed a maximum pixel value of $\mathrm{N}_{\max }$.

\section{LOCATION OF STUDY AREA AND DATA COLLECTION}

The observations were carried out at 11 locations which eight are located at east coast states in Peninsular Malaysia. Observation locations included beaches and hills facing the eastern horizon. Locations were far from city and populated areas to avoid light pollution and street lights.

Observations were carried out on moonless morning skies to avoid natural light such as moon light. The observations dates ran from February to December 2017 except September, since the author was in Mecca. There was a total of 64 days of observations. 60 days' worth of data was recorded while rain occurred for four days.

Malaysia is located in the equatorial region and has a tropical rainforest climate. The local climates are generally hot and humid throughout the year. A large amount of cloud cover is present over the mainland. Therefore, to determine the effects of the weather on dawn visibility, observations were carried out under fine and overcast weather conditions with cloud cover from 4 to 8 okta, respectively. The altitude of cloud at the local horizon was measured approximately using a quadrant and handy guide. Current weather forecasts and cloud cover data for the observer's location were found online from www. accuweather.com.

\section{METHODS}

The sun depression angle measurements were performed using a DSLR camera, Canon 60Da. This camera was fitted with a Tamron 28-300 mm aspherical lens. The Canon 60Da has a CMOS sensor with 18 megapixels, a size 22.30 $\times 14.90 \mathrm{~mm}$, outputs 14-bit RAW and JPEG file image format and has an aperture range between $\mathrm{f} / 3.5$ and $\mathrm{f} / 22$, ISO setting between 100-6400 and shutter speed between $30-1 / 8000 \mathrm{~s}$.

The camera constant $\mathrm{K}_{\mathrm{c}}$ was determined earlier. To determine $\mathrm{K}_{\mathrm{c}}$, a known luminance $\mathrm{L}_{\mathrm{s}}$ source, a white paper lit by a candle at one-foot distance, was chosen. Its known luminance $\mathrm{L}_{\mathrm{s}}$ was $0.29 \mathrm{~cd} / \mathrm{m}^{2}$ (Hiscocks 2004). A common wax candle with dimensions $13 \mathrm{~cm}$ (diameter) $\times 19 \mathrm{~cm}$ (height) was used for the calibration. A common wax candle emits light with a luminous intensity of roughly one candela (Woodford 2018). The DSLR camera was aimed at this white paper and the value $\mathrm{N}_{\mathrm{d}}$ of the pixels in the image was determined.

The pixel value $\mathrm{N}_{\mathrm{d}}$ of the images should not exceed the maximum in order to avoid the loss of information in the image and to ensure the images of dawn recorded were the same as the real dawn seen with naked eye. For 
this purpose, the camera was setup with setting; camera mode: manual; exposure time: 4-10 s; aperture: f/3.5 f/4.5; and ISO sensitivity: 1250-2500. Focus was set to infinity. The DSLR camera was aimed horizontally to the known azimuth of sunrise with a magnetic compass. Shooting began $100 \mathrm{~min}$ before sunrise. Images were shot each min for $60 \mathrm{~min}$. The images were saved in RAW and JPEG formats. A series of images of the sky near the eastern horizon with local time was recorded each day of observation. The image of the dawn was determined by look through the brightness of the images which is the first from the series of the images turns to bright. The local time was recorded corresponding with the image of dawn. The local time of dawn can be converted to sun depression angle with the formula:

$$
\text { Sun depression angle, } \begin{aligned}
\mathrm{D}_{\mathrm{o}}= & \sin ^{-1}(\sin \varphi \sin \delta \\
& +\cos \varphi \cos \delta \cos H)
\end{aligned}
$$

where $\varphi$ is the right accension of the sun; $\delta$ is the declination of the sun; and $H$ is the hour angle.

The luminance of the RAW images was analyzed using AIP4Win software. The JPEG images were analyzed in Photoshop CS5 and Windows Live Photo Gallery software. To measure the luminance of dawn, the pixel values, $\mathrm{N}_{\mathrm{d}}$ of dawn images were read from RAW images using AIP4win software. A rectangle region above the horizon on the image of dawn was selected. The Pixel Tool function in AIP4win was used to measure the pixel value, $\mathrm{N}_{\mathrm{d}}$, in the selected region. The value of Dawn luminance, $\mathrm{L}$ was calculated by using the formula (1).

\section{RESULTS AND DISCUSSION}

Firstly, in order not to lose the information in the images, the camera settings including f/stop, ISO and exposure time were calibrated and the camera constant $\mathrm{K}_{\mathrm{c}}$ was calculated. The value of $\mathrm{K}_{\mathrm{c}}$ was calculated by using the formula (1) and the mean of the $K_{c}$ value is 300 .
An example of the calculation of $\mathrm{K}_{\mathrm{c}}$ is as follows:

Image information:

Date of the image taken: Febuary 19, 2018 (number of frame; IMG 7129)

$\begin{array}{lcc}\text { Quantity } & \text { Symbol } & \text { Value } \\ \text { Pixel Value } & \mathrm{N}_{\mathrm{d}} & 6796 \\ \text { ISO } & \mathrm{S} & 1600 \\ \text { f-stop } & \mathrm{f}_{\mathrm{s}} & 4.5 \\ \text { exposure } & \mathrm{t} & 1.0 \mathrm{~s} \\ \text { Luminance } & \mathrm{L} & 2.9\end{array}$

(White paper lit by candle)

Plug these values into formula (1) and solve for calibration constant $\mathrm{K}_{\mathrm{c}}$;

$$
\begin{aligned}
& \mathrm{K}_{\mathrm{c}}=\frac{N_{d} f^{2}}{L t s} \\
& \mathrm{~K}_{\mathrm{c}}=296.59 \approx 300
\end{aligned}
$$

The frequency of calibration of the Kc values was eight throughout the study.

Figure 1(a) shows the relation between the pixel number, $\mathrm{N}_{\mathrm{d}}$ of the raw images of dawn and $1 /$ (f/stop number $)^{2}$. The lower $\mathrm{f} / \mathrm{stop}$ setting is $\mathrm{f} / 10$. Below this value, the image is too dark. Since the light hit the white paper at one foot is bright then the upper f/stop setting is setup at $\mathrm{f} / 4.5$. If the $\mathrm{f} / \mathrm{stop}$ setting is higher than this value, the image becomes too bright. Therefore, these values were chosen for the camera setting. The results showed that the pixel number increases linearly with $1 /(\mathrm{f} / \mathrm{stop})$ for $\mathrm{f}$-stop setting between $\mathrm{f} / 10$ and $\mathrm{f} / 4.5$.

While Figure 1(b) shows the relation between the pixel number; $\mathrm{N}_{\mathrm{d}}$ and exposure time; $\mathrm{t}$ (s) with f/stop setting is $f / 6.3$. Since the light hit the white paper at one foot is bright then the fastest and slowest $t$ setting is $1 / 8000$ s and $1 / 500$ s, respectively. The images become too dark if the $t$ is lower than $1 / 8000$ s and become too bright if $t$ is higher than $1 / 500 \mathrm{~s}$. The results showed that the pixel number increased linearly with exposure time. Thus, the results

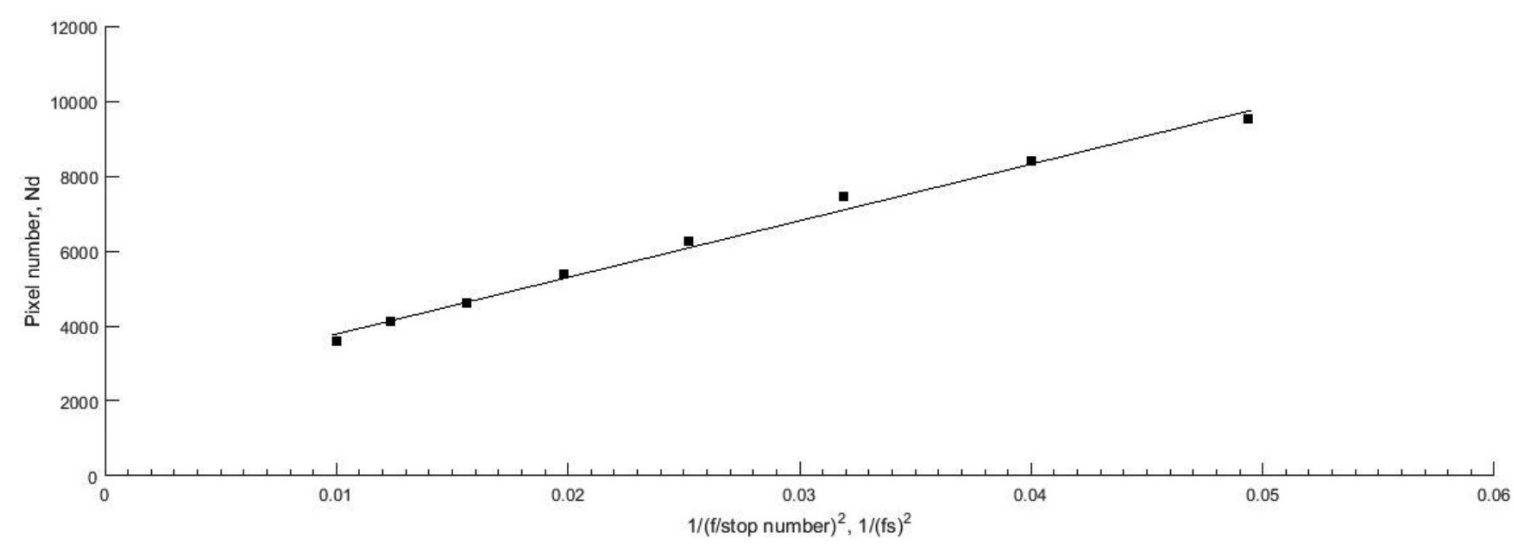

FIGURE 1(a). The relation between Pixel number, $\mathrm{N}_{\mathrm{d}}$ and $\mathrm{f}$-stop number, $\mathrm{f}_{\mathrm{s}}$ 


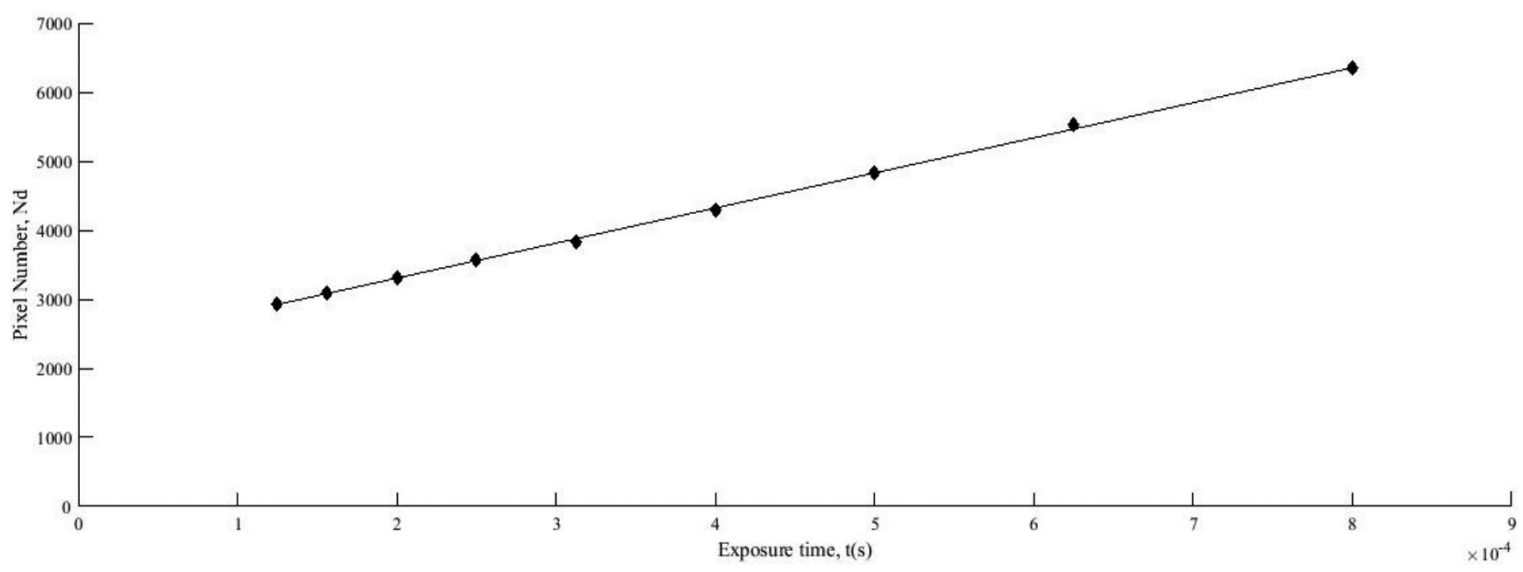

FIGURE 1(b). The relation between Pixel number, $\mathrm{N}_{\mathrm{d}}$ and exposure time, $\mathrm{t}(\mathrm{s})$

indicated that the camera settings were correct and that the camera was calibrated properly.

The observations log included dates, locations, camera setting, sky condition and time of observation were recorded. Table 1 shows one of the observations log for dates, 1-5 June and 3-7 July 2017 at Pekan, Pahang. No observation was done on 2 of June because it was raining.

For the dates 1-5 June 2017, the camera settings were set according to the weather conditions. The upper sky and horizon were cloudy. Since clouds cause reflections, the sky appears a bit brighter; thus, the ISO was set to 1000 . On 7 July 2017 had the clearest sky and Venus, Aldebaran, Taurus and other stars were seen with naked eye. ISO was set to 2500 due to the dark sky. On 3 July 2017, the upper sky was clear but the horizon was cloudy.

Table 2 shows the result for the dates in Table 1. The results showed the solar depression angle, $\mathrm{D}_{\mathrm{o}}$ between $-15^{\circ}$ and $-18^{\circ}$. On 4 June and 7 July $2017, \mathrm{D}_{\mathrm{o}}$ was $-18^{\circ}$. The horizon was cloudy on both dates, but the dawn was seen between the clouds. The sky become contrasting gradually when dawn first appeared between the clouds. On the other dates, dawn was seen a bit later due to thick clouds on the horizon.

Figure 2 shows the photographs of the sky when dawn was seen on cloudy and fine days. On fine days, the stars in the background sky and sky are brighter than on cloudy days. The results indicate that on cloudy days, the first visibility of dawn was late.

Figure 3 shows a series of images and a histogram of sky brightness on 7 July 2017. The histogram shows the pixel value of the image and the numbers of pixel. Figure 3(a) and 3(b) shows the sky were still dark. Figure 3(c) shows the first visibility of dawn when sky started to brighten and the pixel values on the histogram started to increase. Figures 3(d), 3(e) and 3(f) show the brightness of the sky increasing as depicted in the histogram. When the dawn was first seen dark clouds started to appear. This is because the light of dawn makes dark clouds contrast with the sky background.

Meanwhile, Figure 4(a) shows a photograph of eastern horizon which is still dark when the sun depression angle, $\mathrm{D}$ is at $-20^{\circ}$. Figure 4 (b) shows a photograph when the $\mathrm{D}$ is at $-16^{\circ}$ with a very dim light of dawn horizontally. This

TABLE 1. Observation log

\begin{tabular}{|c|c|c|c|c|c|c|c|c|c|}
\hline \multirow{2}{*}{ Date } & \multirow{2}{*}{ Location } & \multirow{2}{*}{$\begin{array}{l}\text { Latitude / } \\
\text { longitude }\end{array}$} & \multicolumn{4}{|c|}{ Camera setting } & \multicolumn{3}{|c|}{ Sky condition } \\
\hline & & & ISO & Aper. & Exp. & Lens & Forecast & $\begin{array}{c}\text { Cloud cover } \\
\%\end{array}$ & $\begin{array}{c}\text { Cloud Altitud } \\
\text { At Horizon }\end{array}$ \\
\hline $1 / 6 / 18$ & Pekan Pahang & $\begin{array}{c}3^{\circ} 24^{\prime} 29^{\prime \prime} / \\
103^{\circ} 21^{\prime} 22^{\prime \prime}\end{array}$ & 1000 & 3.5 & $10 ”$ & $28 \mathrm{~mm}$ & Cloudy & 82 & $6^{\circ}$ \\
\hline $2 / 6 / 17$ & Pekan Pahang & $\begin{array}{c}3^{\circ} 24^{\prime} 29^{\prime \prime} / \\
103^{\circ} 21^{\prime} 22^{\prime \prime}\end{array}$ & 1000 & 3.5 & $10 ”$ & $28 \mathrm{~mm}$ & Rain & NA & NA \\
\hline $3 / 6 / 17$ & Pekan Pahang & $\begin{array}{c}3^{\circ} 24^{\prime} 29^{\prime \prime} / \\
103^{\circ} 21^{\prime} 22^{\prime \prime}\end{array}$ & 1000 & 3.5 & $10 ”$ & $28 \mathrm{~mm}$ & $\begin{array}{c}\text { Intermitten } \\
\text { cloud }\end{array}$ & 71 & $10^{\circ}$ \\
\hline $4 / 6 / 17$ & Pekan Pahang & $\begin{array}{l}3^{\circ} 24^{\prime} 29^{\prime \prime} / \\
103^{\circ} 21^{\prime} 22^{\prime \prime}\end{array}$ & 1000 & 3.5 & $10 ”$ & $28 \mathrm{~mm}$ & Cloudy & 81 & $6^{\circ}$ \\
\hline $5 / 6 / 17$ & Pekan Pahang & $\begin{array}{l}3^{\circ} 24^{\prime} 29^{\prime \prime} / \\
103^{\circ} 21^{\prime} 22^{\prime \prime}\end{array}$ & 1000 & 3.5 & $10 ”$ & $28 \mathrm{~mm}$ & Cloudy & 97 & $10^{\circ}$ \\
\hline
\end{tabular}

Aper. : aperture; Exp : exposure; NA : Not available 
TABLE 2. Results

\begin{tabular}{|c|c|c|c|c|c|c|c|c|}
\hline \multirow[b]{2}{*}{ Date } & \multirow[b]{2}{*}{ Location } & \multirow{2}{*}{$\begin{array}{l}\text { Latitude/ } \\
\text { Longitude }\end{array}$} & \multicolumn{3}{|c|}{ Time of Observation } & \multirow{2}{*}{$\begin{array}{c}\text { Solar } \\
\text { depression } \\
\text { angle, } \mathrm{D}_{\mathrm{o}}\end{array}$} & \multirow{2}{*}{$\begin{array}{l}\text { Pixel Value } \\
\text { of dawn } \\
\text { image, Nd }\end{array}$} & \multirow{2}{*}{$\begin{array}{c}\text { Luminance of } \\
\text { dawn } \\
\left(\mathrm{Cd} / \mathrm{m}^{2}\right)\end{array}$} \\
\hline & & & Start & $\begin{array}{c}\text { First } \\
\text { visibility }\end{array}$ & End & & & \\
\hline $1 / 6 / 18$ & $\begin{array}{l}\text { Pekan } \\
\text { Pahang }\end{array}$ & $\begin{array}{l}3^{\circ} 24^{\prime} 29^{\prime \prime} / \\
103^{\circ} 21^{\prime} 22^{\prime \prime}\end{array}$ & 05.30 & 05.48 & 06.12 & -17.36 & 2087 & 0.00852 \\
\hline $2 / 6 / 17$ & $\begin{array}{l}\text { Pekan } \\
\text { Pahang }\end{array}$ & $\begin{array}{c}3^{\circ} 24^{\prime} 29^{\prime \prime} / \\
103^{\circ} 21^{\prime} 22^{\prime \prime}\end{array}$ & NA & NA & NA & NA & NA & NA \\
\hline $3 / 6 / 17$ & $\begin{array}{l}\text { Pekan } \\
\text { Pahang }\end{array}$ & $\begin{array}{l}3^{\circ} 24^{\prime} 29^{\prime \prime} / \\
103^{\circ} 21^{\prime} 22^{\prime \prime}\end{array}$ & 05.31 & 05.42 & 06.13 & -17.32 & 2103 & 0.00862 \\
\hline $4 / 6 / 17$ & $\begin{array}{l}\text { Pekan } \\
\text { Pahang }\end{array}$ & $\begin{array}{l}3^{\circ} 24^{\prime} 29^{\prime \prime} / \\
103^{\circ} 21^{\prime} 22^{\prime \prime}\end{array}$ & 05.17 & 05.40 & 06.17 & -18.00 & 2119 & 0.00865 \\
\hline $5 / 6 / 17$ & $\begin{array}{l}\text { Pekan } \\
\text { Pahang }\end{array}$ & $\begin{array}{l}3^{\circ} 24^{\prime} 29^{\prime \prime} / \\
103^{\circ} 21^{\prime} 22^{\prime \prime}\end{array}$ & 5.25 & 05.50 & 06.17 & -15.45 & 2079 & 0.00844 \\
\hline $3 / 7 / 17$ & $\begin{array}{l}\text { Pekan } \\
\text { Pahang }\end{array}$ & $\begin{array}{l}3^{\circ} 24^{\prime} 29^{\prime \prime} / \\
103^{\circ} 21^{\prime} 22^{\prime \prime}\end{array}$ & 05.35 & 05.55 & 06.32 & -15.50 & 2109 & 0.00538 \\
\hline $4 / 7 / 17$ & $\begin{array}{l}\text { Pekan } \\
\text { Pahang }\end{array}$ & $\begin{array}{c}3^{\circ} 24^{\prime} 29^{\prime \prime} / \\
103^{\circ} 21^{\prime} 22^{\prime \prime}\end{array}$ & 05.33 & 05.53 & 06.17 & -16.24 & 2103 & 0.00537 \\
\hline $5 / 7 / 17$ & $\begin{array}{l}\text { Pekan } \\
\text { Pahang }\end{array}$ & $\begin{array}{l}3^{\circ} 24^{\prime} 29^{\prime \prime} / \\
103^{\circ} 21^{\prime} 22^{\prime \prime}\end{array}$ & 05.25 & 05.53 & 06.20 & -16.24 & 2138 & 0.00349 \\
\hline $6 / 7 / 17$ & $\begin{array}{l}\text { Pekan } \\
\text { Pahang }\end{array}$ & $\begin{array}{l}3^{\circ} 24^{\prime} 29^{\prime \prime} / \\
103^{\circ} 21^{\prime} 22^{\prime \prime}\end{array}$ & 05.25 & 05.51 & 07.24 & -16.54 & 2095 & 0.00559 \\
\hline 7/7/17 & $\begin{array}{l}\text { Pekan } \\
\text { Pahang }\end{array}$ & $\begin{array}{c}3^{\circ} 24^{\prime} 29^{\prime \prime} / \\
103^{\circ} 21^{\prime} 22^{\prime \prime}\end{array}$ & 05.30 & 05.46 & 06.27 & -18.06 & 2119 & 0.00433 \\
\hline
\end{tabular}
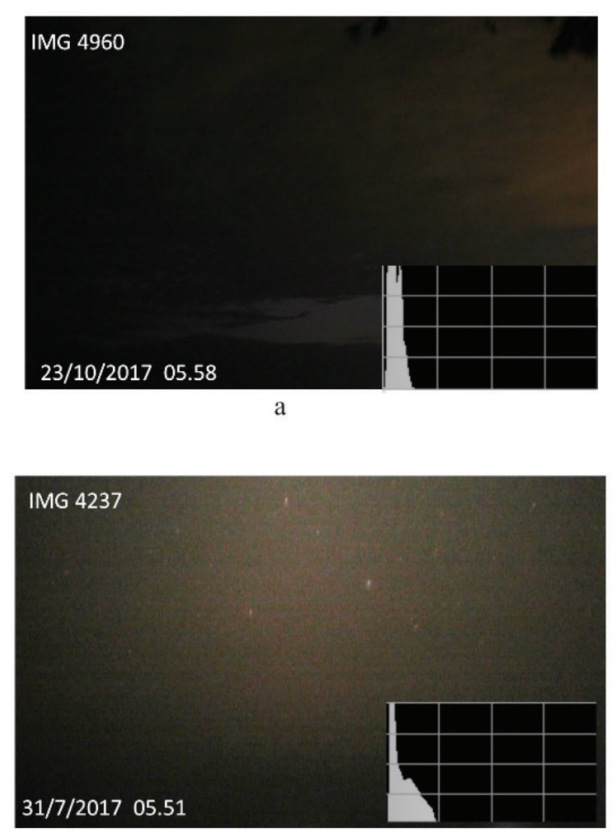

c

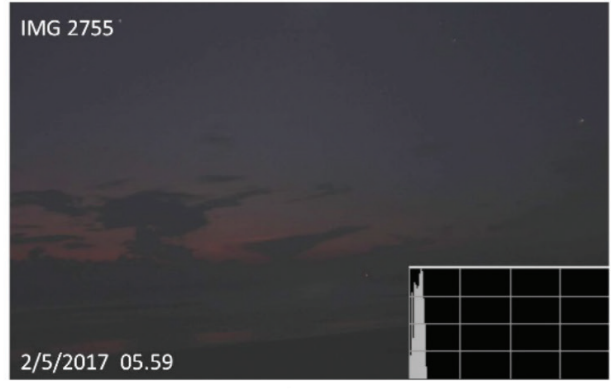

b

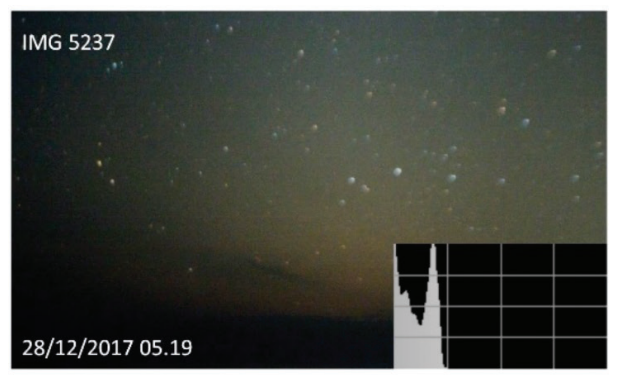

d

FIGURE 2. The dawn on cloudy and fine day

photograph was taken at Kuala Terengganu, August 2, 2017. The images show that the sky ranges from dark until a certain $\mathrm{D}$, after which it becomes bright. The first light is very dim. Then, the sky becomes brighter and brighter gradually. The first light detected is the light of dawn. This result indicates that no light was detected when the $\mathrm{D}$ was at $-20^{\circ}$ and the first light of dawn occured when the $\mathrm{D}_{\mathrm{o}}$ reached $-16^{\circ}$.

Figure 5(a) shows the scattering of the luminance, $\mathrm{L}$ $\left(\mathrm{Cd} / \mathrm{m}^{2}\right)$ of the dawn images first seen over the observation days. The $\mathrm{L}$ values were calculated by pluging in the 


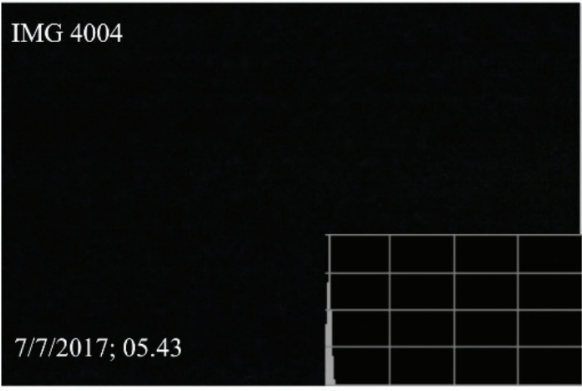

a
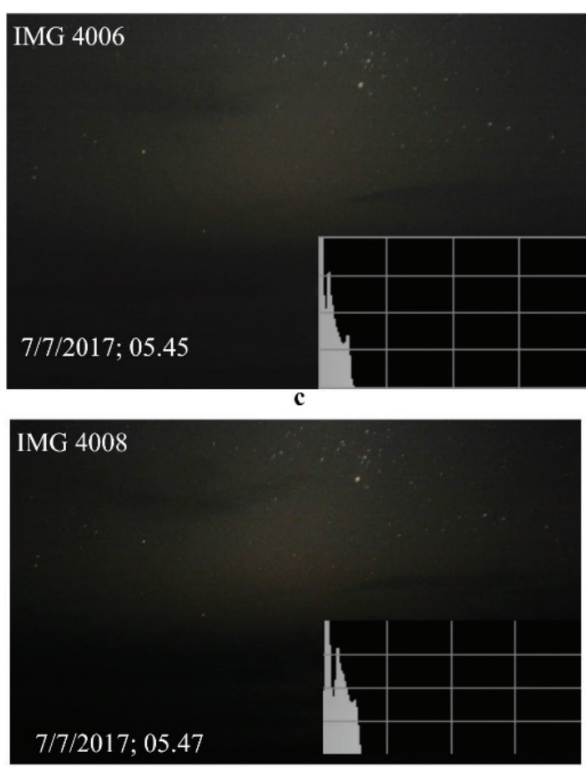

e
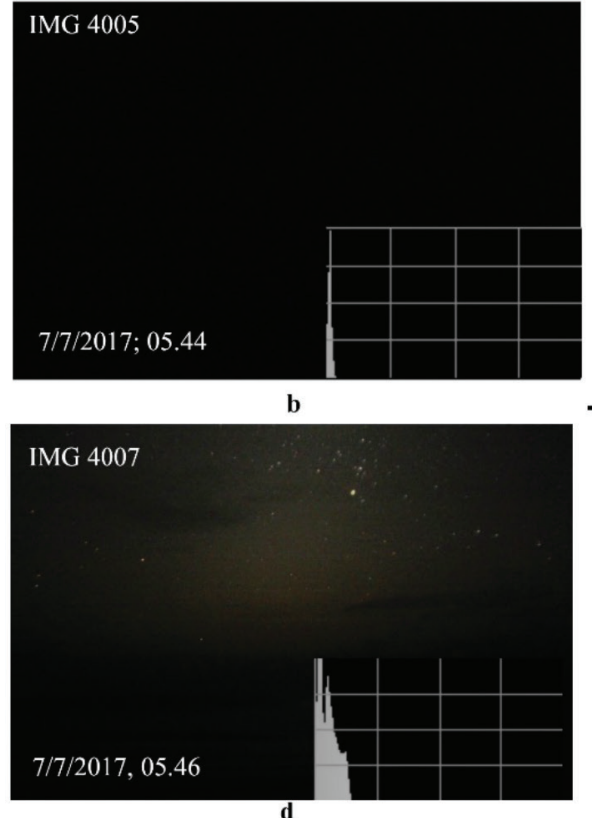

IMG 4009

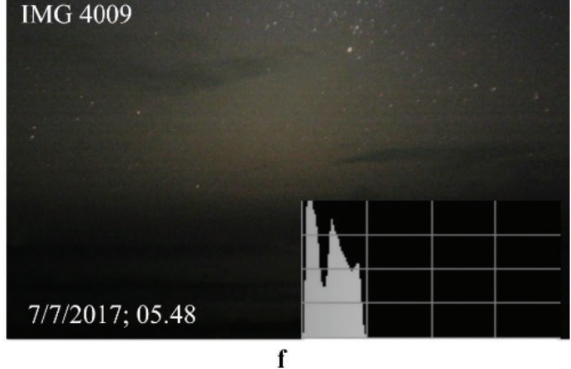

The sky at eastern horizon before dawn rising (a \& b)

The sky at eastern horizon at first visibility of dawn rising $(\mathrm{c})$ and after rising $(\mathrm{d}$, e and $f$ ).

FIGURE 3. Images of dawn

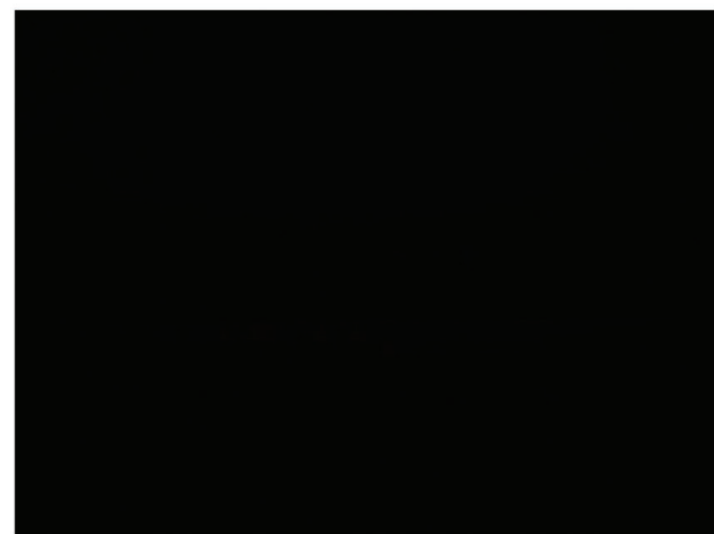

4(a)

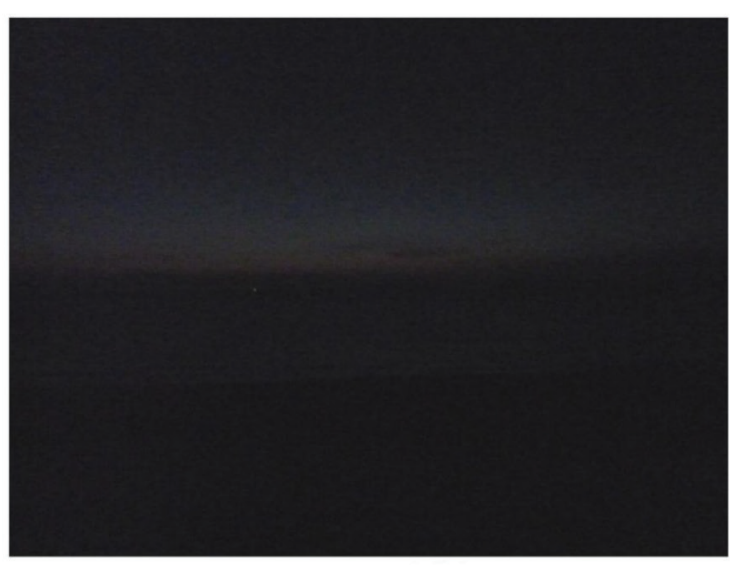

4 (b)

FIGURE 4. East horizon when sun depression angle $\mathrm{D}_{\mathrm{o}}$ at $-20^{\circ}$ and $2(\mathrm{~b})$ at $-16^{\circ}$

calculated camera constant, Kc and the camera setting into the formula (1). The calculated $\mathrm{L}$ was to ensure that the light captured by DSLR camera is light of dawn. The values of $\mathrm{L}$ were compared with the standard value of twilight (when the sun at altitude -9). If the L calculated value is lower than the standard value, this shows the light captured by the DSLR camera is the light of dawn. This study also intends to get the significant value of luminance of dawn measured by DSLR.

The results showed the luminance of dawn with the minimum $\mathrm{L}$ value is $0.0035 \mathrm{Cd} / \mathrm{m}^{2}$ and the maximum is $0.03286 \mathrm{Cd} / \mathrm{m}^{2}$. Figure $5(\mathrm{~b})$ shows the frequency of $\mathrm{L}$. The highest frequencies of the $\mathrm{L}$ values are between 0.005 and $0.009 \mathrm{Cd} / \mathrm{m}^{2}$, with 26 days observations having these 


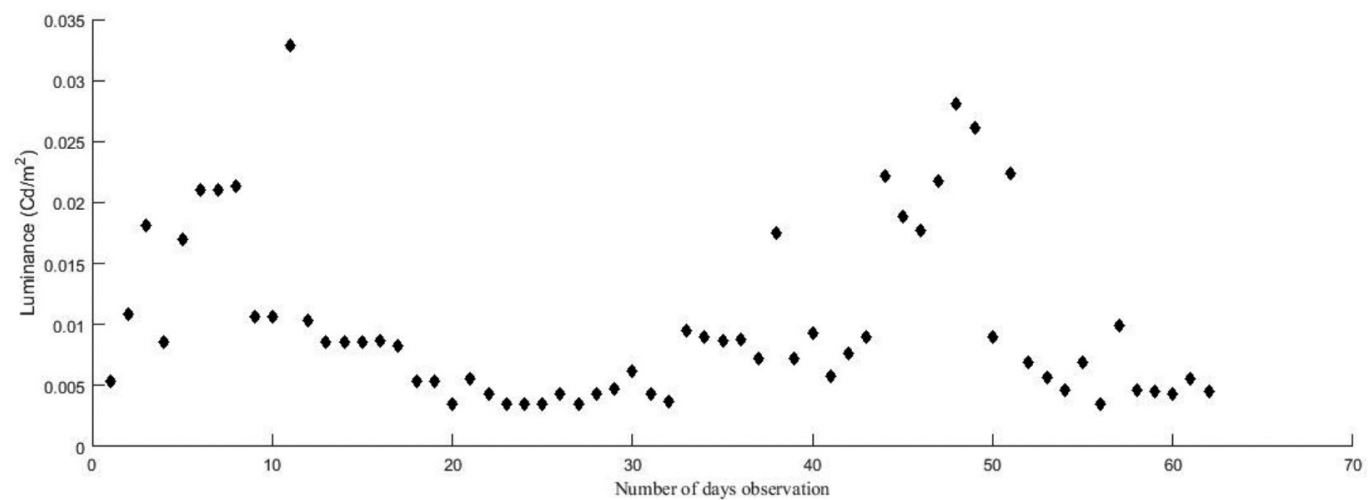

FIGURE 5(a). The scattering of the luminance of the dawn

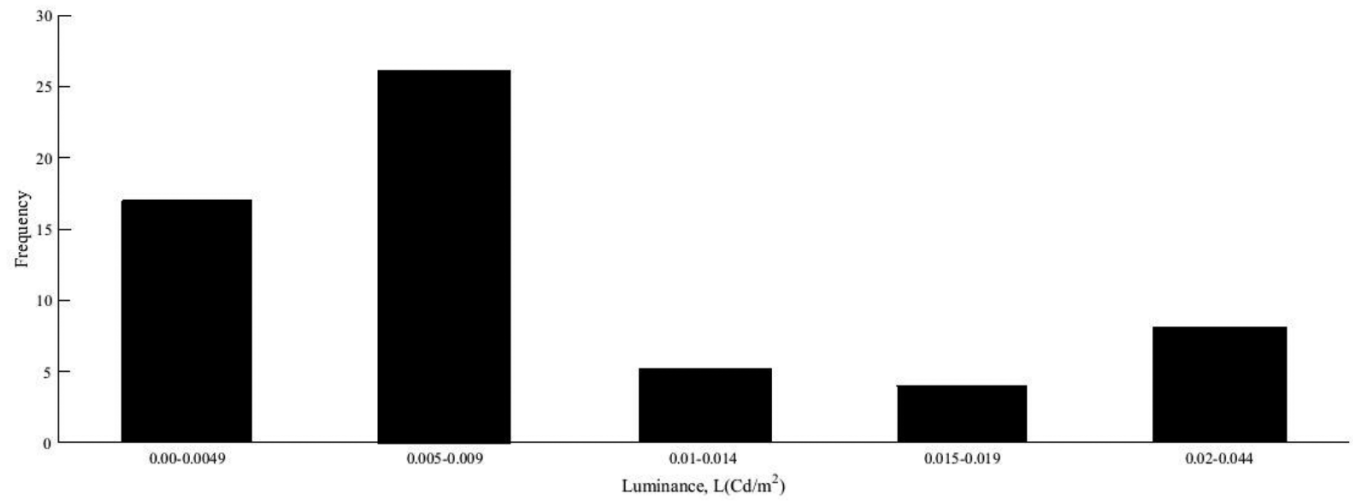

FIGURE $5(\mathrm{~b})$. The frequency of dawn luminance

values. The mean L value is $0.01004 \mathrm{Cd} / \mathrm{m}^{2}$ with a standard deviation of 0.007 . Meanwhile, the result of $\mathrm{L}$ value studied by Kishida (1989) at Kyushu, Japan was $0.16 \mathrm{Cd} / \mathrm{m}^{2}$, when the solar depression is $-9^{\circ}$. Meanwhile, the standard value of horizontal sky luminance was $0.01-0.1 \mathrm{Cd} / \mathrm{m}^{2}$ when the sun reached $-9^{\circ}$ altitude (Hiscock 2014). This shows that the mean L values are lower than the value, L by Kishida (1989) and the standard sky luminance. It is indicated that the light captured by DSLR camera is the light of dawn. The results show the luminance of the first light of dawn is very low when the sun's altitude is lower $\left(-17^{\circ}\right)$ than $-9^{\circ}$.
Figure 6(a) shows the scattering of sun depression angle $\mathrm{D}_{\mathrm{o}}$ of between $-13.30^{\circ}$ and $-18.35^{\circ}$ below horizon for the locations study in Malaysia and Indonesia. Figure 6(b) represents the distribution of the $\mathrm{D}_{\mathrm{o}}$ of dawn observation. The most common values of $\mathrm{D}_{\mathrm{o}}$ are $-16.5^{\circ},-17^{\circ}$ and $-18^{\circ}$ at 13,14 and 13 times of day, respectively. Meanwhile the low frequency of $\mathrm{D}_{\mathrm{o}}$ is $-15.5^{\circ}$ with a record of 3 days of observation. The mean value of $\mathrm{D}_{\mathrm{o}}$ is $-16.76^{\circ}$ with the standard deviation of 0.9607 . The sun depression angle $\mathrm{D}$ was calculated according the hour angle, the right ascension and the declination of the sun at the date and local

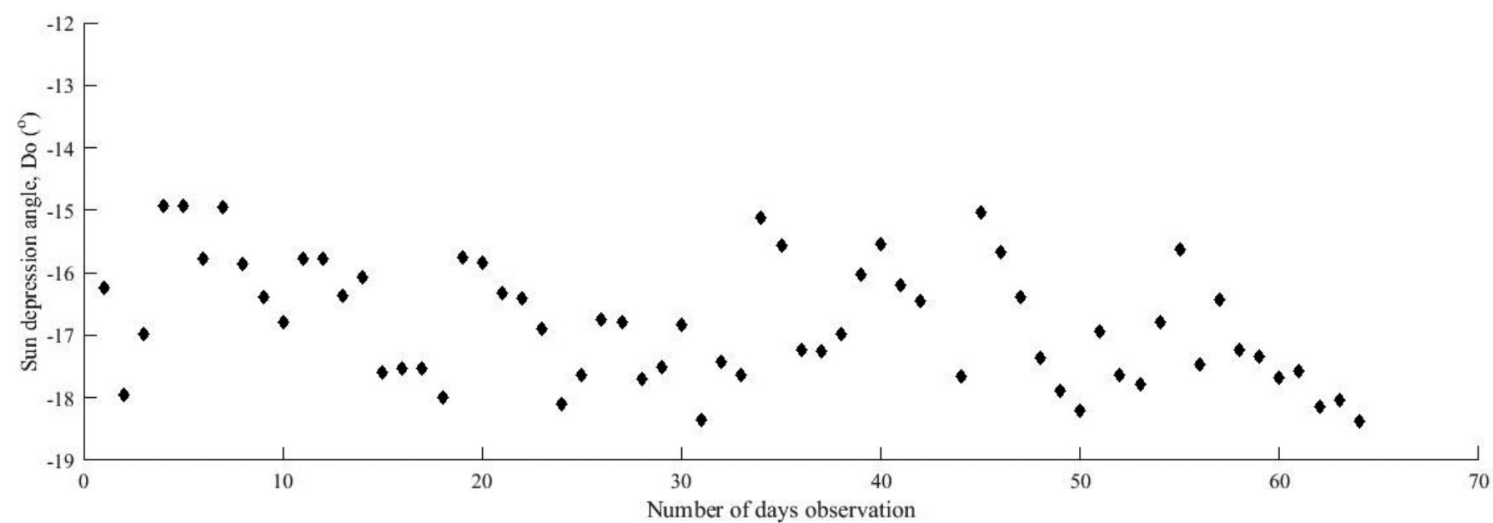

FIGURE 6(a). Scattering of sun depression angle 


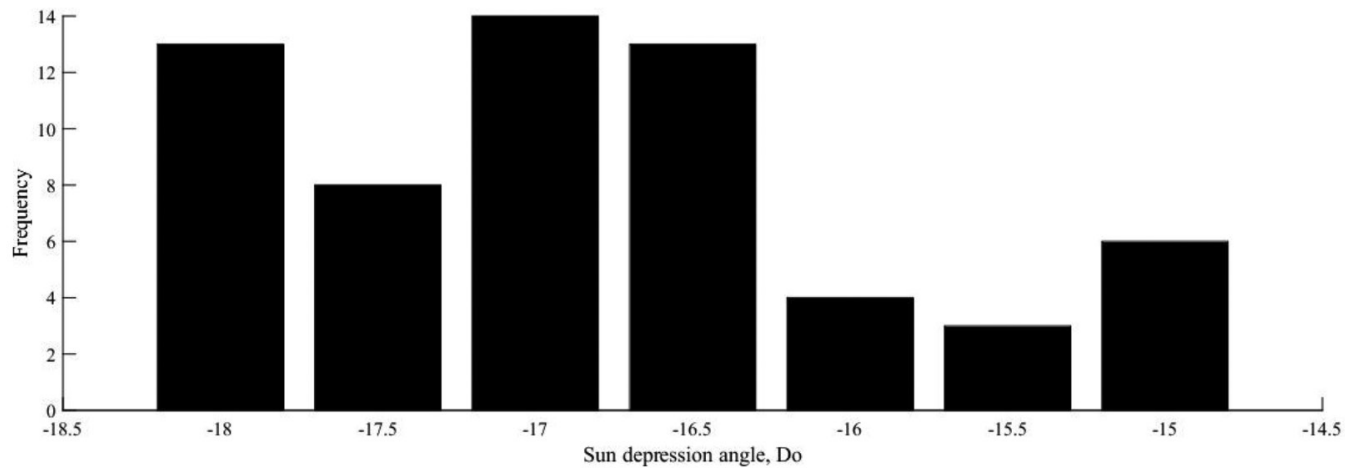

FIGURE 6(b). Frequency of sun depression angle

time when the dawn was first seen by using the formula (3). The early dawn time recorded was on August 3, 2017 at 05.49 , which corresponds to a sun depression angle of $-18.35^{\circ}$. Meanwhile, the latest dawn time recorded was on October 29, 2017 at 06.05 , which corresponds to the sun depression angle is $-13.30^{\circ}$.

This study shows that the minimum value of $\mathrm{D}_{\mathrm{o}}$ was $-18.35^{\circ}$, while the maximum value was $-13.30^{\circ}$ and the mean value was $-16.76^{\circ}$. Hence, we suggest the $D_{0}$ is $-17^{\circ}$, as dawn was most commonly first seen at this angle. The results also showed that the distributions of the $\mathrm{D}_{0}$ were not affected by geographical locations.

The results of $\mathrm{D}_{0}$ agree with a study done by Dani (2016) which used photoelectric techniques in Yogyakarta, Indonesia (The result of $\mathrm{D}_{\mathrm{o}}$ by Dani was $-17^{\circ}$ ). The $\mathrm{D}_{\mathrm{o}}$ values differ from the observations using the naked eye technique in a study done by Hassan et al. (2016) at Sinai, Egypt. The result at Sinai for $\mathrm{D}_{\mathrm{o}}$ was $-14.61^{\circ}$ which is higher than this study. The difference in $\mathrm{D}_{\text {o }}$ between naked eye and digital camera is 2.39 . This difference is due to the sensitivity difference between the naked eye and digital camera. The digital camera has a sensor with high sensitivity to light and can capture low light, unlike the human eye.

From this study, the value of $\mathrm{D}_{\mathrm{o}}\left(-17^{\circ}\right)$ does not agree with the adopted $\mathrm{D}_{0}$ values used in Malaysia, which are $-19^{\circ}$ and $-20^{\circ}$. The differences between these values are $2^{\circ}$ and $3^{\circ}$. Converting $2^{\circ}$ and $3^{\circ}$ gives times of 8 and 10 min earlier, respectively.

\section{CONCLUSION}

Dawn observations were studied for 64 days for the period February to December 2017 at 11 locations in Malaysia and Indonesia. The results of this study are as follows: The DSLR camera can be used for measurement of luminance with significant outcome. The mean luminance $\mathrm{L}$ of dawn is $0.001 \mathrm{Cd} / \mathrm{m}^{2}$; There was no light of dawn when sun depression angle $\mathrm{D}_{\mathrm{o}}$ is at $-19^{\circ}$ and $-20^{\circ}$; and The time of first visibility of dawn was affected by weather or cloud cover on the horizon but not affected by geographical locations. The first light of dawn can be seen when the mean of Do is $-17^{\circ}$.

Hence, we suggested that the new value of sun depression angle $\mathrm{D}_{\mathrm{o}}$ for dawn prayer is $-17^{\circ}$.

\section{REFERENCES}

Baharrudin Zainal. 2002. Pengenalan Ilmu Falak. Dewan Bahasa dan Pustaka. Kuala Lumpur.

Berry, R. \& Burnell, J. 2005. The Handbook of Astronomical Image Processing. $2^{\text {nd }}$ ed. Richmond,VA: Willmann-Bell, Inc.

Chris, W. 2018. The Science of Candle. http://www. explainthatstuff.com/candles.html. Accessed on 22 July 2018.

Dhani Herdiwijaya. 2016. Sky brightness and twilight measurements at Jogyakarta city, Indonesia. Journal of Physics: Conference Series 771: 012033. https://doi. org/10.1088/1742-6596/771/1/012033.

Duriscoe, M. 2016. Photometric indicators of visual night sky quality derived from all-sky brightness maps. Journal of Quantitative Spectroscopy and Radiative Transfer 181:33-45.

Hanel, A., Posch, T., Ribas, S.J., Aubée, M., Duriscoe, D., Jechow, A., Kollath, Z., Lolkema, D.E., Moore, C., Schmidt, N., Spoelstra, H., Wuchterl, G. \& Kyba, C.C.M. 2018. Measuring night sky brightness: Methods and challenges. Journal of Quantitative Spectroscopy and Radiative Transfer 205: 278-290.

Hassan, A.H. \& Yasser A. Abdel Hadi. 2014. Naked eye determination of the dawn at Tubruq of Libya through four years observation. Middle-East Journal of Scientific Research 23(11): 2627-2632.

Hassan, A.H. \& Issa, I.A., Mousa, M. \& Yaser, A. Abdel-Hadi. 2016. Naked eye determination of the dawn for Sinai and Assiut of Egypt. NRIAG Journal of Astronomy and Geophysics 5(1): 9-15.

Hiscocks, P. 2014. Measuring Luminance with a Digital Camera. Syscomp Electronic Design Limited. www.syscompdesign. com.

Ilyas, M. 1984. A Modern Guide to Astronomical Calculation of Islamic Calendar, Times \& Qibla. Kuala Lumpur: Berita Pub. Sdn Bhd. 
Issa, I.A. \& Hassan, A.H. 2008. Eye criteria and times of end and begin of twilights Bahria Egypt NRIAG. Journal Astron. Astrophysis (Special Issue): 413-423.

Kishida, Y. 1989. Changes in light intensity at twilight and estimation of the biological photoperiod. Journal of Japanese Agriculture 22: 4.

Zhang, M., Bakos, G.A., Penev, K., Csubry, Z., Hartman, J.D., Bhatti, W. \& de Val-Borro, M. 2016. Precision multiband photometry with a DSLR camera. Journal of the Astronomical Society of the Pacific 128: 961.

Kassim Bahali* \& Abdul Latif Samian

Institute of the Malay World \& Civilization (ATMA)

Universiti Kebangsaan Malaysia

43600 UKM Bangi, Selangor Darul Ehsan

Malaysia

Nazri Muslim

Pusat Citra Universiti

Universiti Kebangsaan Malaysia

43600 UKM Bangi, Selangor Darul Ehsan

Malaysia
Nurul Shazana Abdul Hamid

School of Applied Physics

Faculty Science and Technology

Universiti Kebangsaan Malaysia

43600 UKM Bangi, Selangor Darul Ehsan

Malaysia

*Corresponding author; email: kassimhb@gmail.com

Received: 15 May 2018

Accepted: 27 July 2018 